\title{
KEUNGGULAN PROVENANS ADAPTIF Eucalyptus occidentalis PADA UJI TERGENANG DAN BERGARAM
}

\author{
(Outstanding Performances of Adaptive Eucalyptus occidentalis_Provenances Under Waterlogging \\ and Salinity Trials)
}

Rina Laksmi Hendrati

Balai Besar Penelitian Bioteknologi dan Pemuliaan Tanaman Hutan

E-mail: rina.l.hendrati@gmail.com

Tanggal diterima: 1 Agustus 2011; Direvisi: 20 September 2011; Disetujui terbit: 8 Januari 2012

\begin{abstract}
Waterloging and salinity in many places in the world are affected by natural conditions, geological history, irrigation practice and replacement of natural vegetations. Ground water might bring salt to soil surface at root zone areas. Engineering and vegetations are commonly used to anticipate this problem. Provisions of vegetations tolerate to this typical salty condition, although take a longer time to solve, are much cheaper and effective means to control salinity and even to rehabilitate the lands. E. occidentalis, a highly tolerant species to those conditions need to be tested as an alternative species for plantation under these conditions. Genetic materials from its natural distribution were tested to find out the most tolerant provenance under inundation and high salt level.

Two controlled testings using $9 \mathrm{E}$. occidentalis provenances were conducted reaching to $300 \mathrm{mM}$ salt and followed by an increased level up to sea salt concentration (550mM NaCl). Provenances from the same genetic materials were also tested in 3 field trials, i.e.: in Roberts, Sandalwindy and Kirkwood with different ranges of salt level.

At salt concentration of 300mM, E. occidentalis growth was not affected, and therefore this level is too low for selection. Plants were depressed under 550mM salt and differences between provenaces are much more obvious. Different performances under high salinity were obtained from controlled condition and in field trials. Provenans Red Lake Siding and Grass Patch originated from the most extreme arid conditions nearby salty lakes showed the best ability to grow under high saline exposures on both testings.
\end{abstract}

Keywords: E. occidentalis, salinity, waterlogging, provenans, selection

\begin{abstract}
ABSTRAK
Penggenangan dan salinitas di berbagai daerah di dunia disebabkan karena berbagai hal termasuk iklim, geologi, irigasi dan hilangnya vegetasi alam. Air tanah yang membawa garam-garam ke permukaan menyebabkan salinitas pada lapisan perakaran tanaman. Penanggulangan fisik dan vegetasi sering dilakukan untuk mengantisipasinya, namun penggunaan vegetasi yang tahan pada lokasi bergaram, meskipun lama, terhitung lebih murah serta lebih menunjang proses rehabilitasi lahan setempat. E. occidentalis, spesies bertoleransi tinggi terhadap kondisi tergenang dan bergaram, perlu diujikan sebagai spesies alternatif untuk penanaman di daearah tersebut. Koleksi materi genetik dari berbagai populasi di sebaran alaminya dicobakan untuk mendapatkan provenans yang paling toleran. Pada penelitian ini seleksi dilakukan baik pada kondisi terkontrol maupun di lapangan.

Dua pengujian dilakukan dengan 9 provenans E. occidentalis pada konsentrasi garam 300mM dilanjutkan dengan pengujian sampai ke level garam air laut $(550 \mathrm{mM} \mathrm{NaCl})$. Provenans dari materi genetik yang sama juga ditanam di 3 lokasi, yaitu di Roberts, Sandalwindi dan Kirkwood dengan level kadar garam yang berlainan.

Pada konsentrasi garam 300mM, pertumbuhan E. occidentalis terbukti tidak terganggu sehingga level ini terlalu rendah untuk pelaksanaan seleksi. Sedangkan level 550mM menimbulkan tekanan tinggi terhadap pertumbuhan tanaman sehingga perbedaan antar provenans terlihat jelas. Perbedaan terhadap tekanan garam tinggi ini diperoleh pada
\end{abstract}


uji terkontrol dan uji lapangan. Provenans Red Lake Siding dan Grass Patch yang berasal dari kondisi paling ekstrim di daerah kering di sekitar danau bergaram, menunjukkan kemampuannya yang terbaik pada kondisi garam tinggi di kedua uji.

Kata kunci: E. occidentalis, salinitas, tergenang, provenans, seleksi

\section{PENDAHULUAN}

Penggenangan dan salinitas yang terjadi di berbagai dareah di dunia dapat disebabkan karena kondisi alam, iklim, sejarah geologi, praktek irigasi, serta penghilangan vegetasi alam dengan tanaman pertanian. Kenaikan air tanah dari penggenangan menyebabkan terbawanya garam-garam dari lahan yang salin tersebut keatas permukaan tanah hingga mencapai lapisan perakaran pertanaman. Lahan dengan kadar garam tinggi umumnya tanahnya tidak berstruktur baik sehingga diberbagai bagian sering terjadi penggenangan. Dua jenis penanggulangan, vegetasi dan fisik, sering dilakukan untuk mengantisipasinya. Penanggulangan melalui penanaman vegetasi yang tahan pada lokasi tersebut, meskipun lama, dianggap lebih murah dan sekaligus bermanfaat untuk merehabilitasi lahan dibandingkan dengan pembuatan bangunan yang ditujukan untuk memudahkan drainasi (Hunt dan Gilkes 1992).

Jumlah spesies pohon yang mampu hidup pada lokasi kering (arid) dan kadar garam yang meningkat sangat terbatas (Hart et al. 1991). Tanaman yang diketahui toleran pada daerah tersebut akan sangat bermanfaat karena problem salinitas banyak terdapat di dunia, termasuk
Afrika utara, Timur Tengah, Pakistan, India, dan barat daya Amerika (Marcar and Crawford 1996; Abou-Hadid 2003). Ada 17 spesies tanaman yang diklasifikasikan sangat toleran terhadap kondisi garam dari genus Eucalyptus, Acacia, Melaleuca dan Casuarina yang beberapa diantaranya bisa dimanfaatkan kayunya (Marcar and Crawford 2004). E. occidentalis merupakan salah satu spesies pohon yang punya ketahanan tinggi terhadap garam dan penggenangan dan jenis ini diharapkan mampu untuk melindungi lahan marginal akibat genangan dan salinitas.

E. occidentalis ditemukan tumbuh pada berbagai kondisi habitat yakni pada kondisi genangan, salinitas tinggi, pada pinggiran sungai dan dekat dengan danau bergaram serta di area kering (Chippendale 1973, Zohar dan Moreshet 1987, Marcar et al. 2000, Harwood et al. 2001, Marcar dan Crawford 2004). Lokasi atau lingkungan tertentu dari habitat alam suatu spesies disebut provenans. Di tempat tersebut, spesies yang dimaksudkan telah hidup sampai beberapa generasi dan diperkirakan telah beradaptasi pada habitat setempat (Marcar dan Crawford 2004). Pada penelitian ini pengujian dengan memilih 9 provenans E. occidentalis 
dari berbagai habitat dilakukan berdasarkan pada hasil seluruh provenans (25) terkoleksi yang diujikan pada level garam $300 \mathrm{mM}$ (moderat) (Mulcahy 2005). Penelitian kali ini yang menggunakan 9 provenans terpilih tersebut, lebih ditingkatkan pada kondisi yang lebih ekstrim yakni pada level garam 550mM.

\section{BAHAN DAN METODE}

\section{Bahan Tanaman}

Sembilan provenans $E$. occidentalis dari 25 provenans yang telah diuji pada kondisi garam tergenang (Mulcahy 2005) dipilih untuk pengujian lanjut pada penelitian ini. Koleksi materi genetik (biji) dari berbagai distribusi alaminya di Australia barat disemaikan untuk digunakan dalam penelitian ini.

\section{Tahap Penelitian}

Penaburan biji dengan baki yang mempunyai 64 pot mini $(3,5 \times 3,5 \times 5 \mathrm{~cm})$ dilakukan pada media pot (Premium P/CM, Baileys Fertilizers, Perth). Penggunaan 25 provenans pada perlakuan garam (konsentrasi garam 0-300 mM) di bulan Maret-Juni 2004 telah dilakukan oleh Mulcahy 2005. Penelitian kali ini yang dilakukan pada bulan Oktober 2004-Januari 2005, dilaksanakan dengan dilanjutkan ke level garam 550mM. menggunakan 9 provenans terpilih dari 25 provenans uji awal. Sembilan provenans tersebut diseleksi dari perwakilan tertinggi, medium dan terendah berdasarkan nilai proporsional uji pertama (Mulcahy 2005) terhadap persen hidup, tinggi, pertumbuhan tinggi relatif dan proporsi daun akhir (\%). Sejumlah 1.200 semai umur 8 bulan berasal dari 9 provenans (30 famili) diletakkan secara acak pada 4 tanki uji, 2 minggu sebelum penerapan salinitas. Semai dari taburan yang sama (9 provenans) juga digunakan untuk penanaman di 3 lokasi, yaitu Roberts, Kirkwood dan Sandalwindi, Australia barat.

\section{Pelaksanaan uji terkontrol}

Tiga jenis perlakuan beserta kontrol diaplikasikan pada uji pertama dan kedua yakni; kontrol (K), tergenang (T), bergaram kering (GK) dan bergaram-tergenang (GT). Perlakuan kering (kontrol dan garam-kering) dilaksanakan dengan cara penyiraman tanki berisi tanaman menggunakan pompa yang terhubung dengan bak air bernutrisisi (Three Part Perfection, Wanneroo, Western Australia) untuk penyiraman 3 kali sehari (masing-masing 30 menit). Perlakuan tergenang dan tergenang bergaram diterapkan dengan menggenangi 2 tangki berbeda menggunakan air bernutrisi dan diganti setiap minggu. Pada pengujian ini, konsentrasi dilakukan hingga konsentrasi garam air laut (550mM $\mathrm{NaCl}, \mathrm{CaCl}_{2}$ ) serta didiamkan 2 minggu pada konsentrasi tertinggi, sehingga total berlangsung sampai 12 minggu.

\section{Pelaksanaan uji lapangan}

Semai dari 9 provenans (30 famili, 15 tanaman/famili) didesain dengan 5 blok. 
ditanam dengan jarak tanam $2 \mathrm{~m}$ x $5 \mathrm{~m}$ di Australia Barat. Kondisi dari masing-masing lapangan. Penanaman dilakukan bulan Juli 2004 lokasi disajikan pada Tabel 1.

di lokasi Kirkwood, Roberts dan Sandalwindy,

Tabel 1. Kondisi umum lokasi uji di lapangan

\begin{tabular}{|l|l|c|c|l|l|}
\hline \multicolumn{1}{|c|}{ Lokasi } & \multicolumn{1}{|c|}{$\begin{array}{c}\text { Garis lintang } \\
\text { dan } \\
\text { Garis bujur }\end{array}$} & $\begin{array}{c}\text { Elevasi } \\
\text { (m dpl) }\end{array}$ & $\begin{array}{c}\text { Curah } \\
\text { Hujan } \\
\text { (mm/tahun) }\end{array}$ & $\begin{array}{c}\text { Suhu Bulanan } \\
\text { (Rata-rata maksimum dan } \\
\text { minimum harian) }\end{array}$ & $\begin{array}{c}\text { Kondisi tanah } \\
\text { saat penanaman }\end{array}$ \\
\hline Kirkwood & $\begin{array}{l}34^{\circ} 27^{\prime} 38^{\prime \prime} . \mathrm{S} \\
117^{\circ} 43^{\prime} 21^{\prime \prime} \mathrm{E}\end{array}$ & 187 & $583-847$ & $\begin{array}{l}14-27.3^{\circ} \mathrm{C} \\
5.7-14.9^{\circ} \mathrm{C}\end{array}$ & Lapisan topsoil kering tanpa tanaman \\
\hline Roberts & $\begin{array}{l}34^{\circ} 37^{\prime} 30^{\prime \prime} \mathrm{S} \\
117^{\circ} 38^{\prime} 9^{\prime \prime} \mathrm{E}\end{array}$ & 300 & $583-747$ & $\begin{array}{l}14.0-27.3^{\circ} \mathrm{C} \\
5.7-14.9 \mathrm{C}\end{array}$ & $\begin{array}{l}\text { Terdapat beberapa genangan air diantara } \\
\text { gundukan tanaman }\end{array}$ \\
\hline Sandalwindy & $\begin{array}{l}33^{\circ} 18^{\prime} 27^{\prime \prime} \mathrm{S} \\
117^{\circ} 20^{\prime} 25^{\prime \prime} \mathrm{E}\end{array}$ & 256 & $372-469$ & $\begin{array}{l}14-30.3^{\circ} \mathrm{C} \\
4,9-15^{\circ} \mathrm{C}\end{array}$ & Terdapat bagian-bagian yang tergenang \\
\hline
\end{tabular}

Level salinitas diukur pada masing-masing tanaman di lapangan menggunakan EM-38 (Geonics, Mississauga, Canada) serta diklasifikasikan sesuai Marcar et al. (1995). Kalibrasi pembacaan EM-38 dilakukan dengan mengambil sampel tanah kedalaman 0-20, 2040 dan $40-75 \mathrm{~cm}$.

\section{Pengukuran dan analisis data}

Persen hidup dan tinggi tanaman pada uji terkontrol dicatat pada level 550mM. Pertumbuhan relatif dihitung dengan rumus ((tinggi akhir - tinggi awal/tinggi awal)*100\%).

Sebelum dan sesudah pengamatan semua daun dihitung periodik setiap minggu serta ditandai untuk menghitung daun lama dan baru. Rumus proporsi daun akhir adalah ((jumlah daun akhir - jumlah daun awal/jumlah daun awal)*100\%). Untuk uji lapangan, persen hidup direkam bulan April 2005 (umur 9 bulan) serta persen hidup, tinggi dan diameter pada bulan Mei 2007 (umur 33 bulan).
Data dianalisis dengan analisis varians dua arah Genstat 9.2 (VSN International, Oxford) dengan perlakuan dan provenans sebagai faktor. Pengukuran EM-38 yang di lapangan diterapkan sebagai kovariat. Nilai rata-rata diambil jika provenans mempunyai 3 famili atau lebih. Uji lanjutan menggunakan uji Tukey (lsd, $\mathrm{p}<0.05$ ).

\section{HASIL DAN PEMBAHASAN}

\section{Hasil pada kondisi terkontrol}

Perlakuan kondisi bergaram-tergenang yang paling ekstrim pada uji terkontrol, diterapkan karena kondisi ini secara umum banyak didapatkan pada tanah bergaram di Australia yang umumnya menyebabkan karakter tanahnya kurang berpori sehingga mempunyai kemampuan drainase yang rendah (Hunt dan Gilkes 1992), terutama saat hujan di musim dingin (Van der Moezel et al. 1991). Pada pengujian terkontrol terhadap 9 provenans di tingkat salinitas $300 \mathrm{mM}$, perbedaan antar perlakuan tidak mempengaruhi tanaman dari 
segi persen hidup dan semua tanaman masih memproduksi daun secara memadai. Pengujian yang melibatkan 25 provenans pada level salinitas $300 \mathrm{mM}$ juga tidak menunjukkan perbedaan dari segi persen hidup maupun proporsi daun akhir, kecuali pada perlakuan tergenang (Mulcahy 2005). Namun pada kondisi tergenang tersebut, proporsi daun yang meningkat dari saat awal samasekali tidak akan mengganggu pertumbuhan. Pada kondisi (GT) 300mM garam, 4 provenans, Red Lake Siding, Young River dan Grass Patch menunjukkan tinggi tanaman yang terbaik namun tidak menunjukkan perbedaan pertumbuhan relative pada kondisi tergenang ( $\mathrm{T}$ ) dan bergaramtergenang (GT). Sehingga level garam ini tidak mempengaruhi pertumbuhan E. occidentalis secara umum. Bagi tanaman lain, level salinitas ini sebenarnya sudah sangat tinggi. Pada level salinitas yang hanya 100-120mM, tanaman pertanian, lupin dan gandum telah menunjukkan adanya kerusakan di dalam tubuh tanaman (Munns 2002, Hu dan Schmidhalter 1998). Sementara pada tanaman Eucalyptus viminalis dan E. smithii, level garam 300mSm-1 telah memberikan kematian $87 \quad \% \quad$ dan $67 \quad \%$ (Meddings et al. 2001). Namun pada penelitian ini, level garam $300 \mathrm{mM}$ terbukti tak bisa digunakan untuk seleksi E. occidentalis karena menunjukkan kematian $0 \%$.

Pada pengujian sampai 550mM, penampilan 9 provenans ternyata menunjukkan persen hidup yang bervariasi antar perlakuan dengan perlakuan bergaram-tergenang menunjukkan persen hidup yang terrendah (47 \%) (Tabel 2). Hal yang sama juga terjadi pada proporsi daun akhir yang secara nyata berbeda antar perlakuan. Respons tanaman pada kondisi bergaram umumnya adalah bahwa kelebihan garam yang terserap oleh tanaman akan diakumulasi pada daun sehingga daun akan menguning dan akhirnya gugur (Munns 2002). Perlakuan garam telah menyebabkan hanya sekitar setengah dari daun (101 dan 116 \%) dapat dipertahankan dibandingkan dengan perlakuan tanpa garam (194 dan 237 \%). Namun persen hidup antar provenans tidak berbeda nyata, termasuk pada perlakuan garam kering dan garam tergenang yang mendekati garam air laut. Hal ini menunjukkan bahwa semua provenans sama-sama mengalami kondisi tertekan. Pada tingkat garam yang tinggi ini, variabel proporsi daun akhir (\%) yang menentukan kehidupan dan tinggi tanaman menunjukkan perbedaan yang sangat nyata antar provenans terutama pada kondisi garam tergenang (GT). Sebagian besar provenans di bawah kondisi garam tergenang level $550 \mathrm{mM}$ ini mempunyai proporsi daun akhir yang sangat rendah sampai pada tingkat $40 \%$ penurunannya dari daun asalnya. Kedua karakter pertumbuhan ini berbeda antar provenans di bawah garam tergenang, sehingga level garam $550 \mathrm{mM}$ ini menunjukkan kemampuan dalam membedakan 
antar provenans, terutama dari kemampuannya untuk mempertahankan daun bagi pertumbuhan selanjutnya. Dua provenans, Red Lake Siding dan Grass Patch masih merupakan provenans dengan pertumbuhan terbaik pada semua perlakuan.

\section{Hasil di lapangan}

Level salinitas bervariasi pada 3 lokasi uji. Pada kedalaman 25 cm Sandalwindy mempunyai salinitas moderat $(530 \mathrm{mS} / \mathrm{m})$ sampai ekstrim $(1990 \mathrm{mS} / \mathrm{m})$ di bulan Mei serta moderat (200-700mS/m) pada bulan August 2005. Level ini bervariasi pada kedalaman 50 cm, dari 83 - 960mS/m di bulan Mei dan 320 2080mS/m di bulan Agustus. Roberts mempunyai level salinitas yang lebih tinggi daripada Sandalwindy $(20-7300 \mathrm{mS} / \mathrm{m})$. Di lokasi Kirkwood karena kondisinya yang tergenang, salinitas berkisar antara 578 - 1286 $\mathrm{mS} / \mathrm{m}$, namun Roberts dan Kirkwood punya kisaran yang hampir sama di kedalaman $25 \mathrm{~cm}$. Roberts dan Sandalwindy berturutan mempunyai pH 5.16 - 6.66 dan 5.21-7.55, sedang Kirkwood mempunyai $\mathrm{pH}$ tertinggi (6.52 - 8.17)

Sembilan provenans yang sama (Tabel 3) dengan provenans yang diujikan pada kondisi terkontrol (Tabel 2) mengindikasikan persen hidup yang tinggi 90\% dengan kematian 10\% sampai umur 33 bulan, kecuali di Kirkwood yang menunjukkan kematian sampai 53\% pada umur 9 bln karena mengalami penggenangan air bergaram sampai beberapa bulan. Pada umur 33 bln, tanaman di Kirkwood tidak lagi diamati (kematian <30\%). Tingginya pH di Kirkwood dan kandungan lempung yang tinggi diperkirakan menyebabkan tingginya kematian tanaman. Di Roberts dan Sandalwindy, terdapatnya bercak-bercak air di permukaan tanah di antara gundukan yang ditemui saat penanaman diperkirakan mempengaruhi tingginya persen hidup di 2 lokasi tersebut. Persen hidup yang tinggi dan tidak terdapatnya perbedaan yang nyata pada pertumbuhan relatif antar provenans menunjukkan bahwa masingmasing provenans mempunyai kemampuan yang sama pada kondisi bergaram pada tahap awal kehidupan sampai umur lebih dari 2,5 tahun. Oleh karenanya kedua karakter, persen hidup dan pertumbuhan relatif, kurang tepat jika dijadikan kriteria seleksi E. occidentalis di lapangan pada level salinitas di atas. Sementara dari segi karakter pertumbuhan tinggi dan diameter, perbedaan antar provenans terlihat sangat nyata yang mengindikasikan bahwa karakter ini dimungkinkan merupakan respons dari tanaman pada kondisi ini. Dari segi tinggi, 2 provenans unggul pada kondisi terkontrol, Red Lake Siding dan Grass Patch juga menunjukkan kemampuannya untuk tumbuh terbaik, terutama Red Lake Siding yang juga disertai dengan keunggulan diameter yang terbesar di lokasi Roberts. 
Tabel 2. Pengujian terhadap garam dan garam tergenang setelah 12 minggu dari 9 provenans E. occidentalis pada level garam 550 mM NaCl. A. Persen hidup (\%), Proporsi daun akhir (\%) B. Tinggi (cm) dan Pertumbuhan relatif (\%)

\begin{tabular}{|c|c|c|c|c|c|c|c|c|c|}
\hline \multirow{2}{*}{$\begin{array}{l}\text { A. } \\
\text { Provenans }\end{array}$} & \multicolumn{3}{|c|}{ Persen hidup (\%) } & \multirow[b]{2}{*}{ GT } & \multicolumn{5}{|c|}{ Proporsi daun akhir (\%) } \\
\hline & $\mathrm{K}$ & $\mathrm{T}$ & GK & & $\mathrm{K}$ & $\mathrm{T}$ & GK & GT & \\
\hline $\begin{array}{l}\text { Gordon River (1) } \\
\text { Lake Magenta (2) }\end{array}$ & $\begin{array}{l}100 \\
100\end{array}$ & $\begin{array}{c}100 \\
95\end{array}$ & $\begin{array}{l}50 \\
90\end{array}$ & $\begin{array}{l}60 \\
60\end{array}$ & $\begin{array}{l}261 \pm 0 \\
217 \pm 4\end{array}$ & $\begin{array}{c}215 \pm 0 \\
151 \pm 15\end{array}$ & $\begin{array}{c}74 \pm 0 \\
118 \pm 5\end{array}$ & $\begin{array}{l}100 \pm 0 \\
96 \pm 13\end{array}$ & $\begin{array}{l}\mathrm{b} \\
\mathrm{b}\end{array}$ \\
\hline $\begin{array}{l}\text { Truslove (1) } \\
\text { Grass Patch (3) }\end{array}$ & $\begin{array}{c}100 \\
93 \pm 3\end{array}$ & $\begin{array}{l}100 \\
100\end{array}$ & $\begin{array}{c}80 \\
90 \pm 6\end{array}$ & $\begin{array}{c}60 \\
53 \pm 3\end{array}$ & $\begin{array}{c}227 \pm 0 \\
210 \pm 21\end{array}$ & $\begin{array}{c}203 \pm 0 \\
170 \pm 19\end{array}$ & $\begin{array}{c}103 \pm 0 \\
113 \pm 15\end{array}$ & $\begin{array}{l}131 \pm 0 \\
93 \pm 20\end{array}$ & $\begin{array}{l}a \\
b\end{array}$ \\
\hline Katanning (3) & $97 \pm 3$ & 100 & $83 \pm 9$ & $50 \pm 6$ & $215 \pm 19$ & $203 \pm 11$ & $100 \pm 5$ & $89 \pm 3$ & bc \\
\hline Red Lake Siding (8) & $90 \pm 3$ & 100 & $74 \pm 4$ & $45 \pm 6$ & $226 \pm 16$ & $193 \pm 9$ & $87 \pm 9$ & $75 \pm 4$ & c \\
\hline Beaufort River (5) & $96 \pm 2$ & $98 \pm 2$ & $78 \pm 5$ & $36 \pm 12$ & $231 \pm 15$ & $216 \pm 15$ & $102 \pm 5$ & $76 \pm 6$ & c \\
\hline Young River (5) & $98 \pm 2$ & 100 & $78 \pm 6$ & $34 \pm 8$ & $244 \pm 9$ & $193 \pm 12$ & $108 \pm 6$ & $68 \pm 8$ & $\mathrm{~cd}$ \\
\hline Stirling Range (2) & 95 & 95 & 75 & 25 & $211 \pm 7$ & $197 \pm 8$ & $100 \pm 38$ & $61 \pm 0.1$ & $d$ \\
\hline Rata-rata & 97 & 99 & 78 & 47 & 237 & 194 & 116 & 100.6 & \\
\hline
\end{tabular}

Antar perlakuan dan antar provenans ns

Antar perlakuan *** (Isd $=11)$

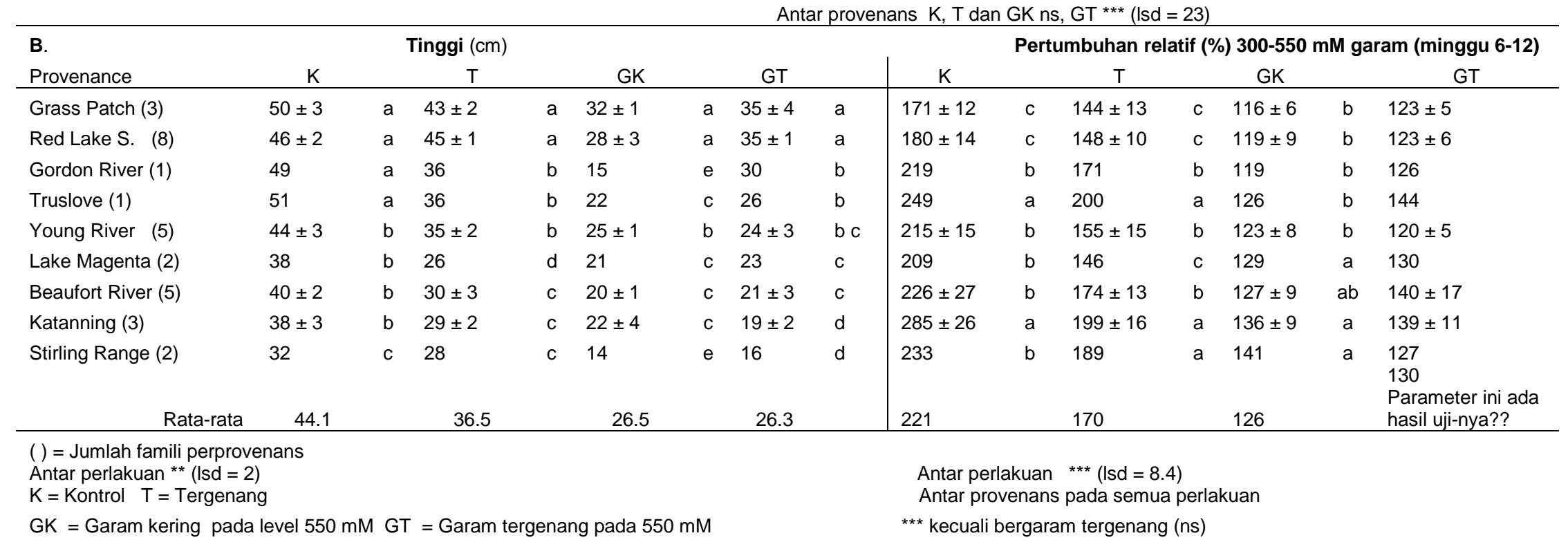


Tabel 3. A. Persen hidup (9 dan 33 bulan), B. Tinggi (9 dan 33 bulan) serta C. diameter dan pertumbuhan relatif pada 33 bulan dari provenans E. occidentalis pada 3 uji lapangan bergaram di Kirkwood, Roberts dan Sandalwindy

\begin{tabular}{lccc|cc}
\hline A. & \multicolumn{2}{c}{ Persen hidup 9 bulan (\%) } & \multicolumn{2}{c}{ Persen hidup 33 bulan (\%) } \\
& $\begin{array}{c}\text { Sandalwindy } \\
(\%)\end{array}$ & $\begin{array}{c}\text { Roberts } \\
\text { Provenans }\end{array}$ & $\begin{array}{c}\text { Kirkwood } \\
(\%)\end{array}$ & $\begin{array}{c}\text { Sandalwindy } \\
(\%)\end{array}$ & $\begin{array}{c}\text { Roberts } \\
(\%)\end{array}$ \\
\hline Truslove (2) & $93 \pm 7$ & $100 \pm 0$ & $42 \pm 10$ & $93 \pm 7$ & $100 \pm 0$ \\
Red Lake Siding (3) & $93 \pm 7$ & $96 \pm 5$ & $67 \pm 13$ & $93 \pm 7$ & $96 \pm 5$ \\
Grass Patch (3) & $87 \pm 9$ & $98 \pm 2$ & $60 \pm 12$ & $84 \pm 7$ & $96 \pm 2$ \\
Stirling Range (1) & $100 \pm 0$ & $93 \pm 0$ & $60 \pm 0$ & $93 \pm 0$ & $93 \pm 0$ \\
Beaufort River (3) & $96 \pm 2$ & $93 \pm 4$ & $51 \pm 11$ & $82 \pm 2$ & $91 \pm 5$ \\
Katanning (2) & $100 \pm 7$ & $89 \pm 6$ & $47 \pm 10$ & $93 \pm 0$ & $89 \pm 6$ \\
Lake Magenta (3) & $98 \pm 2$ & $87 \pm 7$ & $49 \pm 11$ & $98 \pm 2$ & $87 \pm 7$ \\
Young River (3) & $100 \pm 0$ & $82 \pm 2$ & $64 \pm 12$ & $100 \pm 0$ & $80 \pm 0$ \\
Gordon River (2) & $93 \pm 0$ & $78 \pm 5$ & $40 \pm 9$ & $73 \pm 7$ & $76 \pm 6$ \\
\multicolumn{1}{c}{ Rata-rata } & 94 & 91 & 53 & 90 & 90 \\
\hline
\end{tabular}

Antar lokasi 9 bulan: * (Isd = 23)

\begin{tabular}{|c|c|c|c|c|c|c|c|c|c|c|}
\hline \multirow{2}{*}{$\begin{array}{l}\text { B. } \\
\text { Provenans } \\
\end{array}$} & \multicolumn{5}{|c|}{ Tinggi umur 9 bulan (cm) } & & \multicolumn{4}{|c|}{ Tinggi 33 bulan $(\mathrm{cm})$} \\
\hline & \multicolumn{2}{|c|}{$\begin{array}{l}\text { Sandalwindy } \\
(\mathrm{cm})\end{array}$} & $\begin{array}{r}\text { Roberts } \\
(\mathrm{cm}) \\
\end{array}$ & \multicolumn{3}{|c|}{$\begin{array}{c}\text { Kirkwood } \\
(\mathrm{cm})\end{array}$} & \multicolumn{2}{|c|}{$\begin{array}{l}\text { Sandalwindy } \\
(\mathrm{cm})\end{array}$} & \multicolumn{2}{|r|}{$\begin{array}{r}\text { Roberts } \\
(\mathrm{cm}) \\
\end{array}$} \\
\hline Red Lake Siding (3) & $99 \pm 0$ & $\mathrm{a}$ & $92 \pm 3$ & $\mathrm{a}$ & $96 \pm 3$ & $\mathrm{a}$ & $331 \pm 7$ & & a & $366 \pm 13$ \\
\hline Grass Patch (3) & $88 \pm 12$ & a & $80 \pm 5$ & $\mathrm{a}$ & $85 \pm 5$ & $\mathrm{a}$ & $327 \pm 1$ & & a & $350 \pm 3$ \\
\hline Truslove (2) & $70 \pm 2$ & $\mathrm{C}$ & $74 \pm 4$ & $\mathrm{~b}$ & $82 \pm 8$ & $\mathrm{a}$ & $300 \pm 5$ & & $\mathrm{~b}$ & $344 \pm 23$ \\
\hline Gordon River (2) & $59 \pm 1$ & $\mathrm{c}$ & $74 \pm 15$ & $\mathrm{~b}$ & $64 \pm 7$ & $\mathrm{c}$ & $300 \pm 7$ & & $b$ & $344 \pm 12$ \\
\hline Stirling Range (1) & $62 \pm 0$ & $\mathrm{c}$ & $63 \pm 0$ & c & $69 \pm 0$ & $\mathrm{~b}$ & $289 \pm 0$ & & c & $334 \pm 0$ \\
\hline Beaufort River (3) & $87 \pm 11$ & $\mathrm{a}$ & $60 \pm 3$ & c & $65 \pm 5$ & c & $335 \pm 1$ & & a & $334 \pm 8$ \\
\hline Katanning (2) & $65 \pm 7$ & $\mathrm{C}$ & $63 \pm 3$ & $\mathrm{C}$ & $79 \pm 6$ & $\mathrm{~b}$ & $306 \pm 2$ & & $b$ & $330 \pm 6$ \\
\hline Lake Magenta (3) & $73 \pm 10$ & $\mathrm{~b}$ & $69 \pm 5$ & $\mathrm{~b}$ & $81 \pm 6$ & $\mathrm{~b}$ & $328 \pm 8$ & & $\mathrm{a}$ & $315 \pm 19$ \\
\hline Young River (3) & $73 \pm 2$ & $\mathrm{~b}$ & $53 \pm 3$ & $\mathrm{C}$ & $71 \pm 3$ & $\mathrm{~b}$ & $305 \pm 1$ & & $b$ & $277 \pm 15$ \\
\hline Rata-rata & 75.0 & & 69.6 & & 76.9 & & 313 & & & 332.6 \\
\hline \multicolumn{11}{|c|}{ Antar lokasi 33 bulan: * (Isd = 17) } \\
\hline \multirow[t]{2}{*}{ C. } & \multicolumn{5}{|c|}{$\begin{array}{l}\text { Diameter at (33 bulan) } \\
(\mathrm{mm})\end{array}$} & \multicolumn{5}{|c|}{$\begin{array}{c}\text { Pertumbuhan relatif 9- } 33 \text { bulan } \\
(\%)\end{array}$} \\
\hline & \multicolumn{3}{|c|}{ Sandalwindy } & \multicolumn{2}{|l|}{ Roberts } & \multicolumn{3}{|c|}{ Sandalwindy } & \multicolumn{2}{|c|}{ Roberts } \\
\hline \multicolumn{11}{|l|}{ Provenans } \\
\hline Red Lake Siding (3) & & \pm 2 & $\mathrm{~b}$ & $43 \pm 2$ & $\mathrm{a}$ & & $08 \pm 40$ & $\mathrm{~b}$ & & $274 \pm 11$ \\
\hline Katanning (2) & & \pm 0 & $\mathrm{~b}$ & $40 \pm 1$ & $\mathrm{~b}$ & & $79 \pm 88$ & $a$ & & $272 \pm 12$ \\
\hline Beaufort River (3) & & \pm 5 & $\mathrm{a}$ & $45 \pm 3$ & $\mathrm{a}$ & & $66 \pm 28$ & $\mathrm{~b}$ & & $269 \pm 7$ \\
\hline Truslove (2) & & \pm 0 & $\mathrm{C}$ & $41 \pm 6$ & $\mathrm{~b}$ & & $08 \pm 19$ & $\mathrm{a}$ & & $269 \pm 10$ \\
\hline Gordon River (2) & & \pm 1 & c & $44 \pm 4$ & $\mathrm{a}$ & & $34 \pm 78$ & $\mathrm{a}$ & & $269 \pm 7$ \\
\hline Grass Patch (3) & & \pm 1 & $\mathrm{~b}$ & $41 \pm 0$ & $\mathrm{~b}$ & & $09 \pm 59$ & $\mathrm{~b}$ & & $268 \pm 4$ \\
\hline Stirling Range (1) & & \pm 0 & $\mathrm{~b}$ & $39 \pm 0$ & $\mathrm{~b}$ & & $95 \pm 0$ & a & & $267 \pm 0$ \\
\hline Lake Magenta (3) & & \pm 4 & a & $38 \pm 4$ & $\mathrm{~b}$ & & $21 \pm 29$ & $\mathrm{~b}$ & & $243 \pm 12$ \\
\hline Young River (3) & & \pm 1 & $\mathrm{~b}$ & $28 \pm 3$ & C & & $72 \pm 42$ & a & & $225 \pm 14$ \\
\hline Rata-rata & & 5.7 & & 40.2 & & & 349 & & & 262 \\
\hline
\end{tabular}

( ): Jumlah famili perprovenans

Antar lokasi: diameter * (Isd $=3.9)$, pertumbuhan relatif ** $($ Isd $=64)$

Perbedaan signifikan $(P>0.01)$ antar provenans ditunjukkan oleh huruf yang berbeda $(a, b, c$ and d) 
Konsistensi dalam hal persen hidup dan tinggi tanaman dari 2 provenans Red Lake Siding dan Grass Patch baik pada kondisi terkontrol bergaram-tergenang sampai $550 \mathrm{mM}$ maupun di lapangan pada salinitas tinggi, mengindikasikan keunggulan dari 2 provenans tersebut. Hal ini membuka kemungkinan eksplorasi lebih lanjut pada resolusi yang lebih tinggi (famili dan individu). Keunggulan pertumbuhan dari 2 provenans tersebut dibandingkan provenans yang lain, baik pada kondisi bergaram maupun tidak bergaram mengindikasikan bahwa karakter pertumbuhan yang baik dimiliki secara umum oleh keduanya dan dimungkinan merupakan karakter yang dikendalikan secara genetik sehingga keduanya merupakan calon yang cocok untuk diobservasi lebih jauh

Variasi pada karakter kuantitatif umumnya mempunyai hubungan dengan seleksi alam dan adaptasi ekologi (Gonzáles-Martínez et al. 2004). Kenyataan menunjukkan bahwa E. occidentalis yang umumnya tumbuh di daerah basah agak asin atau di daearah kering di sekitar danau bergaram terbukti memberikan perbedaan antar provenans. Perbedaan ini mungkin disebabkan karena berbedanya pengembangan adaptasi dalam kurun waktu yang lama (Lowe et al. 2004) pada kondisi bergaram, sehingga level garam yang tinggi diperlukan untuk membedakan diantara provenans tersebut. Pada tanaman pohon Taxodium distichum, perbandingan antara famili dari daerah tak bergaram dan daerah bergaram menunjukkan bahwa yang berasal dari daerah basah bergaram tampil yang terbaik pada kondisi garam yang tinggi (Allen et al. 1994). Eucalyptus globulus yang berasal dari daerah pantai juga menunjukkan persen hidup dan pertumbuhan yang lebih baik pada kondisi bergaram dibandingkan dengan yang berasal dari daratan yang jauh dari pantai (Marcar et al. 2002). Pada studi ini, E. occidentalis yang berasal dari lokasi yang paling ekstrim kering di sekitar danau bergaram, seperti provenans Red Lake Siding dan Grass Patch, tampil dan tumbuh lebih baik pada kondisi garam tinggi dibandingkan dengan yang berasal dari daerah basah bergaram.

Meskipun termasuk mempunyai toleransi yang tinggi pada kondisi bergaram (Marcar dan Crawford 2004), E. occidentalis menunjukkan pengurangan pertumbuhan pada kondisi garam tinggi di lapangan. Dibandingkan dengan penelitian lain, pada umur 9 bulan pada level salinitas $1424 \mathrm{mSm}^{-1}$ di lokasi Roberts, tanaman yang menunjukkan tinggi $(0.7 \mathrm{~m})$ yang kurang dari tanaman 1 tahun (1.3 m) pada level salinitas $1000 \mathrm{mSm}^{-1}$ (Biddiscombe et al. 1981). E. occidentalis diperkirakan akan mulai menunjukkan penurunan pertumbuhan pada level $1000 \mathrm{mSm}^{-1}$ (Pepper and Craig 1986; Benyon et al. 1999). Pada umur 61 bulan, pertumbuhan E. occidentalis berkurang 8\% jika 
ditanam pada level kadar garam 400-1300 mSm

${ }^{1}$ dibandingkan kontrol (0-500 $\left.\mathrm{mSm}^{-1}\right)$. Sebagai pembanding, jenis toleran yang moderat terhadap garam, E. camaldulensis, akan mengalami penurunan sampai $35-54 \%$ pada kondisi 400-1300 mSm${ }^{-1}$ (Marcar et al. 2003). Selanjutnya diinformasikan bahwa pada studi ini, tanaman E. occidentalis pada umur 33 bulan terbukti jauh lebih pendek (3.34 m) dibandingkan tanaman umur 40 bulan (5.8-6.5 m) pada level garam lebih rendah 400-800 $\mathrm{mSm}^{-1}$ (Steven et al. 1999), dan variasi tingkatan garam dari masing-masing uji diperkirakan mempengaruhi perbedaan ini. Meskipun demikian, adanya fakor lain baik dari segi iklim, jenis tanah maupun asal benih yang berbeda dari masing-masing percobaan, diperkirakan juga mempengaruhi perbedaan tersebut.

\section{KESIMPULAN}

1. Pada level garam $550 \mathrm{mM}$, terdapat perbedaan proporsi daun akhir dan tinggi tanaman dari 9 provenan yang diuji. Provenans Red Lake Siding dan Grass Patch merupakan provenans dengan pertumbuhan terbaik pada semua perlakuan

2. Seleksi tepat dilakukan pada range $300 \mathrm{mM}$ $550 \mathrm{mM}$.

3. Pada percobaan di lapangan, pertumbuhan tinggi dan diameter antar provenans berbeda. Dua provenans unggul pada kondisi terkontrol, Red Lake Siding dan Grass Patch juga tumbuh terbaik. Hal ini diperkirakan karena adaptasi yang telah dikembangan oleh kedua provenans tersebut di habitat asalnya.

\section{UCAPAN TERIMA KASIH}

Ucapan terima kasih disampaikan kepada Associate Prof. Julie Plummer dari The University of Western Australia dan Dr. Liz Barbour dari Forest Product Commission Western Australia yang mengarahkan penulisan dan penelitian ini. Penelitian ini merupakan award (hadiah) yang diberikan kepada penulis. Terima kasih juga disampaikan kepada Forest Product Commission yang telah menyediakan dana penelitian, Ryan Abbot dan Len Norris dari persemaian Forest Product Commission di Wanneroo Western Australia yang membantu persiapan dan pelaksanaan penelitian ini, serta kepada Lucy Mulcahy dalam pelaksanaan pengujian awalnya.

\section{DAFTAR PUSTAKA}

Abou-Hadid, A. F. (2003). The use of saline water in agriculture in the Near East and north Africa regions. In "Crop production in saline environments: global and integrative perspectives" (S. S. Goyal, Sharma, SK, and Rains, DM, eds.). Food Production Press, Haworth Press, London, UK

Allen, J. A., Chambers, J. L., and Stine, M. (1994). Prospect for increasing salt tolerance of forest trees: a review. Tree Physiology 14, 843-853.

Benyon, R. G., Marcar, N. E., Crawford, D. F., and Nicholson, A. T. (1999). Growth and water use of Eucalyptus camaldulensis and E. occidentalis on a saline discharge site near Wellington, NSW, Australia. Agricultural Water Management 39, 229- 
244.

Biddiscombe, E. F., Rogers, A. L., and Greenwood, E. A. N. (1981). Establishment and early growth of species in farm plantation near salt seeps. Australian Journal of Ecology 6, 383-389.

Chippendale, G. M. (1973). "Eucalyptus of the Western Australia goldfields (and the adjacent wheat belt)." Govt. Print, Department of Primary Industry, Forestry and Timber Bureau, Canberra, Australia.

Gonzalez-Martinez, S. C., Mariette, S., Ribeiro, M. M., Burban, C., Raffin, A., Chambel, M. R., Ribeiro, C. A. M., Aguiar, A., Plomion, C., Alia, R., Gil, L., Vendramin, G. G., and Kremer, A. (2004). Genetic resources in maritime pine (Pinus pinaster Aiton) molecular and quantitative measures of genetic variation and differentiation among maternal lineages. Forest Ecology Management 197, 103-115.

Hart, B. T., Bailey, P., Edwards, R., Hortle, K., James, K., McMahon, A., Meredith, C., and Swadling, K. (1991). A review of the salt sensitivity of the Australian fresh water biota. Hydrobiologia $\mathbf{2 1 0}$, 105-144.

Harwood, C., Bulman, P., Bush, D., Mazanec, R., and Stackpole, D. (2001). "Compendium of Hardwood Breeding Strategies.." Joint Venture Agroforestry Program (Rural Industries, Land \& Water, Forest and wood Products, Research and Development Corporations), Canberra, Australia.

Hu, Y., and Schmidhalter, U. (1998). Spatial distributions and net deposition rates of mineral elements in the elongating wheat (Triticum aestivum L) leaf under saline soil conditions. Plantarum 25, 212-219.

Hunt, N., and Gilkes, B. (1992). "Farm Monitoring Handbook: a practical down-to-earth manual for farmers and other land users," The University of Western Australia.

Lowe, A., Harris, S., and Ashton, P. (2004). "Ecological genetics: design, analysis and application" Blackwell Publishing, Victoria, Australia.

Marcar, N. E., and Crawford, D. F. (1996). Other produtive uses of saline land: tree-growing strategies. In "4th National Conference and Workshop on the 'Productive use and rehabilitation of saline lands". Promaco Convention, Albany, Western Australia, 25-30 March 1996.

Marcar, N. E., and Crawford, D. F. (2004). "Trees for Saline Landscapes," RIRDC Publication Number 03/108, Canberra. Australia.

Marcar, N. E., Crawford, D. F., Hossain, A. K. M. A., and Nicholson, A. T. (2003). Survival and growth of the tree species and provenances in response to salinity on a discharge site. Australian Journal of Experimental Agriculture 43, 1293-1302.

Marcar, N. E., Crawford, D. F., Saunders, A., Matheson, A. C., and Arnold, R. A. (2002). Genetic variation among and within provenances and families of Eucalyptus grandis W. Hill and E. globulus Labill.
Subsp. globulus seedlings in response to salinity and waterlogging. Forest Ecology Management 162, 231249.

Marcar, N. E., Arnold, R., and Benyon, R. (2000). "Trees for saline environments," http:/www.soilwater.org.au/Ed. Special issue: June 2000, Australian Association of Natural Resource Management.

Marcar, N. E., Crawford, D., Leppert, P., Jovanovic, T., Floyd, R., and Farrow, R. (1995). "Trees for Saltland: a guide to selecting native species for Australia," CSIRO, Division of Forestry, Canberra, Australia.

Meddings, R. L. A., McComb, J. A., and Bell, D. T. (2001). The salt-waterlogging tolerance of Eucalyptus camaldulensis x E. globulus hybrids. Australian Journal of Experimental Agriculture 41, 787-792.

Mulcahy, L. (2005). Screening 25 provenances of Eucalyptus occidentalis for salinity and waterlogging tolerance, The University of Western Australia, Thesis.

Munns, R. (2002). Comparative physiology of salt and water stress. Plant, Cell and Environment 25, 239.

Pepper, R. G., and Craig, G. F. (1986). Resistance of selected Eucalyptus species to soil salinity in Western Australia. Journal of Applied Ecology 23, 977-987.

Stevens, R. M., Sweeney, S. M., Meissner, A. P., Frahn, W. A., and Davies, G. (1999). Survival, growth and water use of a range of tree species irrigated with saline drainage water. Australian Forest 62, 97-105.

Van der Moezel, P. G., Pearce-Pinto, G. V. N., and Bell, D. T. (1991). Screening for salt and waterlogging tolerance in Eucalyptus and Melaleuca species. Forest Ecology Management 40, 27-37.

Zohar, Y., and Moreshet, S. (1987). Provenances of Eucalyptus occidentalis in the Arid Zone of Israel. Forest Ecology Management 22, 71-77. 